\author{
YU.V. ZELENKO, S.V. MIAMLIN ${ }^{1^{*}}$ \\ 1* Dnipropetrovsk National University of Railway Transport, named after V. Lazaryan, 2 Lazaryan Str., 49010, \\ Dnipropetrovsk, Ukraine; tel. +38 (056) 37315 04, e-mail: j.zelenko@mail.ru
}

\title{
ECOLOGIC AND ECONOMIC MEANS OF STABILIZATION AND IMPROVEMENT OF ENVIRONMENT STATE AT THE RAILWAY TRANSPORT
}

The problems of escalation of the ecological situation in the sphere and intensification of negative trends in many sections of transport technologies are conditioned by the proactive rate of transport development and peculiarities of its interaction with the objects of environment. Objective. The required stage of the modern approach to formation of effective system of ecological management at railway station is creation of special ecoinformational system that will the possibility to give an objective evaluation of ecological and economic losses, both in the process of natural resource management and in cases of accidents with negative ecological consequences. Methodology. Development of environment management systems at organization of natural resources management on the base of modern information technologies will give the possibility not only to reduce the frequency of situations, associated with the environment elements pollution, but also to optimize organization of the natural resources management, as high concentration of resources may lead to emergency in adjacent regions of mutually exclusive types of anthropogenic activity. Scientific novelty and practical relevance. There is developed the system of the environment ecological state management is intended for definition of the best options for the natural resources management development with consideration of ecological and economical factors. In the process of development of the scientific bases of the transport ecological safety development, there was carried out the analysis of three main conceptual approaches to safety definition. It is proved, that in recent years, due to measurement of the danger level on the base of introduction of the relevant factor, the proposed scientific and methodological apparatus gives the possibilities of operative management of ecological and economic risks at the railway through constant monitoring with the help of the GIS technologies and system analysis.

Key words: ecological safety, railway transport, eco-information system, ecological losses.

\section{Introduction}

Surface transport for industrially developed regions is one of the leading sectors that considerably influence on economic and that are characterized by the considerable negative influence on the environment.

The analysis of ecological situation in the system "transport - nature - human being" evidences that ecological problems in the sector strengthen and negative trends develop in many sectors of transport technologies from the point of view of their influence on nature [1]. These problems are conditioned by the proactive rate of transport development and peculiarities of its interaction with the objects of environment.

In addition, one of the most dangerous phenomena in the process of transport operation is accidents that are accompanies by the dangerous toxic substances discharge [1, 2].

It is known that the main reasons of accidents are unsatisfactory state of the main production funds, constant breaches of the established requirements as to safe operation, low industrial, technological and labour discipline [1].

\section{Objective}

The strategy of minimization of influence on environment shall be carried out both at the stage of accidents prevention (maintenance, timely diagnostics and replacement) and at the stages of localization and liquidation of accidents consequences. In such a case, special attention shall be drawn to modern innovative methods of the polluted areas recovery and disposal of dangerous waste from liquidation. The required stage of modern approach to formation of effective ecological management 
system at the railway transport is creation of special eco-information system that will give the possibility to give an objective evaluation of ecological and economic losses, both in the process of natural resource management and in cases of accidents with negative ecological consequences.

\section{Methodology}

In the structure of environment ecological state management system the main component is the database, providing system with information and defining its structure, functions and abilities of solution of managerial tasks, based on situation simulation.

The analysis of existing scheme of railway infrastructure ecological safety management shows its imperfection and absence of organized system of obtaining and analysis of data for timely adoption of managerial solutions as to rational natural resources management and minimization of negative influence on the environment in its structure $[1,2]$.

The development of the environment management systems at organization of the natural resources management on the base of modern information technologies will give the possibility not only to reduce the frequency of situations, associated with the environment elements pollution, but also to optimize organization of the natural resources management, as high concentration of resources may lead to emergency in adjacent regions of mutually exclusive types of anthropogenic activity. In such a case the system of environment ecological state management is intended for definition of the best options for the natural resources management development with consideration of ecological and economical factors.

\section{Results}

Thus, in order to minimize economical and ecological losses, arising at transport incidents during transportation, special attention shall be drawn to preventive measures that include modelling of systems for accidents prevention. The process of modelling of the system for prevention of accidental spills and ensuring of ecological safety at transportation includes the stage of the locality model construction with various layers of digital cartographical information, inclusive of maps of reception status of the territories and objects, as well as model of toxicants behavior in environment.

In addition, the analysis of existing conceptual apparatus and existing regulatory base [3] confirms the necessity of harmonization of the field terminology in gradation of transport events of various severity and general state system of terms. The search of reasonable compromise in positions is the necessity, from the point of view of adequate evaluation of risk factors, of both emergency of accidents and forecasted loss from them. Thus, there were defined the discrepancies and contradictions in the sphere of analysis of risks at the railway transport.

Thus, in order to introduce effective system of ecological management at the railway transport there is developed the special eco-information system [4] that contains four functional units: information, analytical, operative and technological.

Scientific novelty and practical relevance. In the process of development of the scientific bases of ecological safety management at transport there was carried out the analysis of three main conceptual approaches to safety definition. It is observed that in recent year, due to intensive development of the fundamental sciences (mathematics, theory of probability, statistics, etc.) there have emerged objective prerequisites for creation of danger level measurement methods on the base of relevant measure introduction [5-7].

System approach to this problem, associated with evaluation and management of risk of transport accidence, in particular, during technological process of oil products transportation along the railway network provides solution of the twostage problem of stochastic programming:

- development of methods of quantitative evaluation of the level of risk of running safety breaches at railway transport;

- development of the mathematical models of the accidents railway transport consequences and selection of rational measures, directed at reduction of risks of their emergency and losses amount in the result of accidents that have already taken place.

In addition, one of the top priority tasks is the definition of danger level through theory of allowable ecological risks for objects and operations, carried out at the railway transport operation.

The right interpretation of allowable natural risks position is the fact that allowable risks shall 
be established by the legislative and regulatory acts at the state and regional levels for social, economic and ecological spheres of possible losses fixation, with their differentiation according to territory and objects of economic activity with consideration of receptivity index and level of danger of such objects for population, as well as economic possibilities for state and its subjects [11-13].

The main tasks of the allowable risks definition is effective utilization of ecological and economic resources.

Statistics proves that the expenditures for prevention of danger (risks prevention) are less than expenditures for their consequences liquidation, i.e. less than loss (risk). In addition, large amounts of money for liquidation of consequences are allocated in urgent order. It is evident that establishment of strict standard of allowable risks will serve as stimulus for minimization of expenditures, associated with dangerous processes risk: allocation of the required means for achievement of the allowable risk level minimizes considerable expenditures for consequences liquidation in case of higher risks levels.

It is impossible to foresee in advance the exact place, time and scales of the oil products spillage. However, in order to ensure effectiveness of measures, associated with prevention and liquidation, there is the complex of regulatory documents, regulating activity of the enterprises, carrying out production, transportation, processing and sale of oil and oil products.

Thus, for a priori evaluation of economic losses at transportation of oil products by the railway transport there shall be evaluated two probable characteristics: danger level (intensity) and receptive status (vulnerability) of the danger object. Successive evaluation of danger, dependent on natural and technology-related conditions and the danger object vulnerability gives the possibility to evaluate the risk of negative processes and further to apply the already developed one and apparatus of risk situations management that is applied in many spheres of economy for reduction of economic losses from the ecological disturbances [7$10]$.

Adequate evaluation of real values of ecologic and economical losses is required not only for optimal functioning of the transport, but also in all the spheres of economy: for evaluation of regional economy total effectiveness, for selection of in- vestment projects, especially of nature protection purpose projects for implementation of ecological insurance principles and so on.

The specific nature of evaluation of the ecological and economic effectiveness of the nature protection measures is defined by special nature of the result of their application and functioning. They are intended for prevention or reduction of losses in the result of dangerous processes. In connection with this fact, it is required to supplement them with recommendations, associated with accounting and evaluation of the prevented loss. The loss, caused by certain recipient, is summarized according to all the recipients of negative action that are considered in this region that requires special attention for accurate, objective evaluation.

At a posteriori evaluation of economic loss from ecological disturbances that have already taken place the main task is the accounting of all the loss components and accurate evaluation of the total value of object subject to negative action as well as of its part that composes losses.

The task of a priori evaluation of economic loss is associated with considerable difficulties. In such cases it is requires to apply different methods of evaluation of losses from permanent ecological disturbances (for example, environment pollution with pollution sources that acts permanently) and from occasional dangerous processes of natural and technology-related nature (floods, accident emissions of dangerous substances, etc.). In the last case, ecological disturbance is considered as probable process.

Moreover, the difficult task is accurate differentiation of quantitative and qualitative negative changes of the environment, made by such object due to so-called underlying qualitative indicators, characteristic for such situation component.

Economic loss from dangerous natural and technology-related, as well as natural processes means estimated monetary value of consequences of their negative actions in respect of recipients (fig. 1). In connection with insufficient study of these actions and impossibility of monetary value estimation of certain social consequences of economic loss indicators application shall be accompanied by informal analysis of both the level of processes knowledge lack and specific social consequences. At the same time, many social consequences are of social-economic nature and have estimated monetary value. 
Negative influence on the side of economic activity or natural cataclysms changes its parameters. Recipients response to such changes. Such response of the recipients forms new parameter of their state.

In order the procedure of the loss evaluation reflects entire sequence of relationship of cause and effect, the first link of which is ecological disturbance, and the last - economic loss, it is proposed to consider the loss as the functions of the following values: process danger level (intensity) and vulnerability level of the territory or object, on which the process influences, i.e. response of the territory (object) to dangerous action.
Such approach complies with the risks definition that is applied in construction at evaluation of loss from dangerous technology-related and natural processes.

Thus, the example are the accidents at oil products transportation. Taking into account that the loss to the environment components is caused both at direct oil or oil products spillage and pollution of soil or water object, and at liquidation of consequences of spillage and disposal of oil containing waste and soil, there is developed the method of evaluation of complex loss, caused to environment in the result of spillage of oil and oil products and further processing of the polluted soils, generated at the railway operation (see fig. 1)

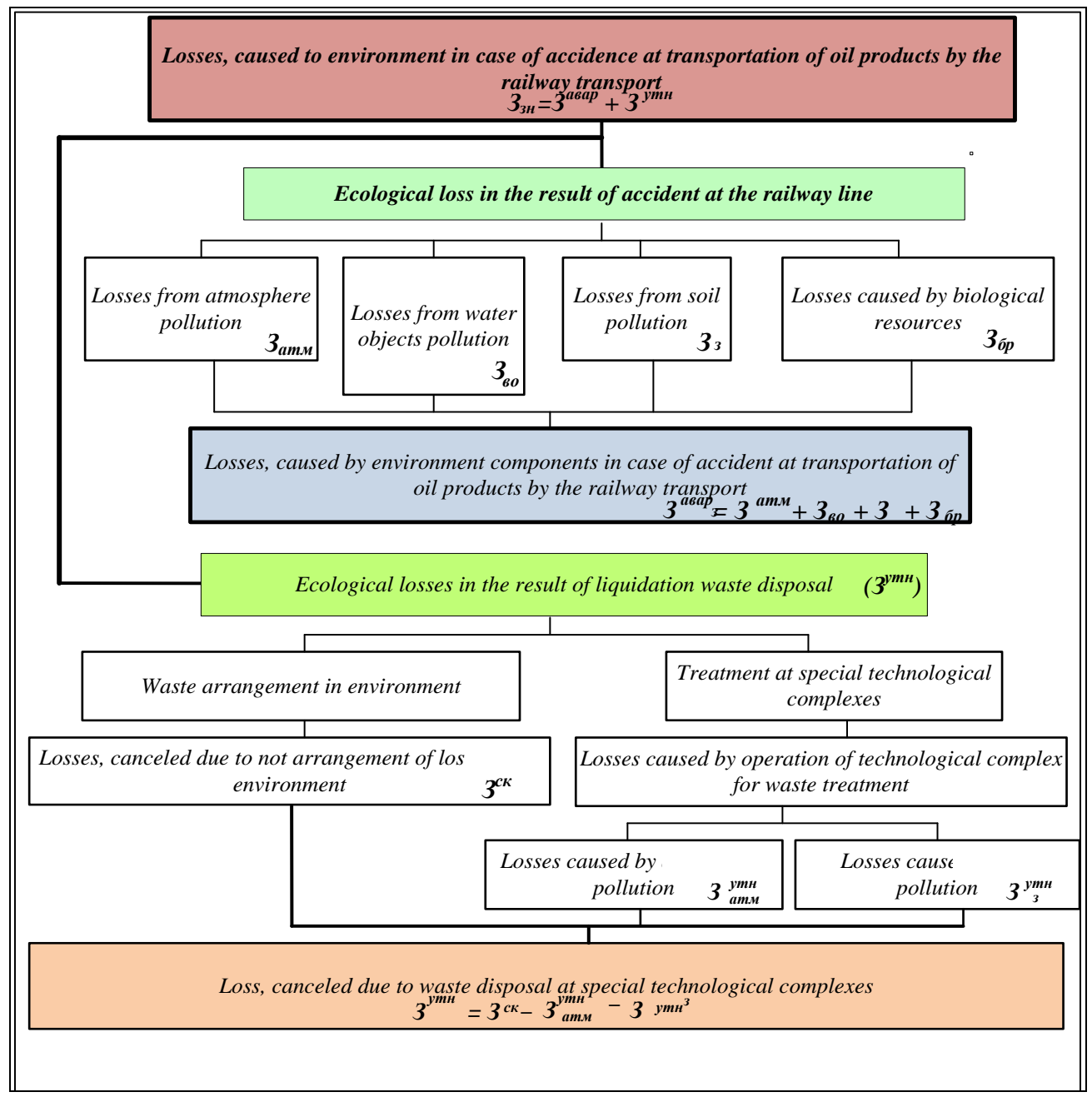

Fig. 1. Algorithm pf ecological losses, caused by accidents at oil products transportation by the railway transport calculation.

Losses, caused by the environment components at the accidents at the railway lines, are defined with consideration of carried out works as to soil, polluted with oils treatment, as amount of direct 
loss from oil or oil products spillage and loss, caused to the environment by the technological complex at polluted with oil soils treatment.

\section{Conclusions}

The proposed scientific-methodological apparatus gives the possibilities of operative management of ecologic and economic risks at the railway lines, especially at oil [products handling, with the help of HIS technologies and system analysis on the base of special software complex.

\section{REFERENCE LIST}

1. V.N. Plakhotnyk. Ecological aspects of accidents at the railway lines of the countries-members of OSJD. // B.N. Plakhotnyk, V.I. Sirakov, Yu.Ya. Xherniavskyi et al. OSJD bulletin, 1997, No.6, p.7-9.

2. V.N. Plakhotnyk. Nature protection activity at the railway transport of Ukraine: problems and solutions.// V.N. Plakhotnyk, L.A. Yaryshkina, V.I. Sirakov, V.T. Tanshyn-K.: Publishing house Transport of Ukraine, 2001, -244p.

3. A.P. Zubko. Eco-safety of railway lines of Ukraine. // A.P. Zubko, V.T. Tanshyn, D.V. Zerkalov. Regulatory documents in two books - K.: Znannia, 1999.

4. Copyright for composition registration certificate. Software System of ecological risks at the railway transport analysis (SAER) / Yu.V. Zelenko, V.V. Tarasov, S.Yu. Trepak;.- No.42639; published on 05.03.12.

5. Yu.V. Zelenko. Scientific bases of ecological safety of transportation technologies and utilization of oil products at the railway transport: monograph / Yu.V. Zelenko. - D.: Publishing House Makovetskyi, 2010. - 242 p.
6. Yu.V. Zelenko. Development of ecological loss and ecological risk evaluation principles at accidents with the oil products at the railway transport Yu.V. Zelenko // Dnipropetrovsk National University of Railway Transport, named after V. Lazaryan Reporter. - Dnipropetrovsk, 2010. No.32. - P. 198-203.

7. Zelenko Yu. Development of nature protection measures at emergency spills of oil products / Yu. Zelenko, L. Yaryshkina// Fourth international conference, Waste management and the environment. - Wessexs Institute of Technology, UK, 2008. P. 243-247.

8. Nocentini M. Bioremediation of a soil contaminated by hydrocarbon mixtures: the residual concentration problem / M. Nocentini, D. Pinelli, F. Fava // Chemosphere. - 2000. - Vol. 41. - P. 11151123.

9. E. J. Henli. Reliability of technical systems and risk evaluation / E.J/ Henli, H. Kumamoto. - M.: Mechanic engineering, 1984.

10. Chapelle F. H. Bioremediation of Petroleum Hydrocarbon-Contaminated Ground Water: The Perspectives of History and Hydrology / F. H. Chapelle// Ground Water. - 1999. - Vol. 37(1). - P. 122-132.

11. Ecological geology of Ukraine: reference aid. - Kyiv: Science, view, 1993. - 407 p.

12. 33.5.5-01-97 Branch Construction Norms guidance. Arrangement and carrying out of ecologic and amelioratory monitoring. K.: IPM UAAN, 1997. - P. 1: Irrigation soils. -94 p.

13. Concept of evaluation of pollution and ecological damage as the initial stage of recovery works at the objects of oil products provision / [V.M. Holdberg, A.I. Arbuzov, S.M. Kazenov et al.] // Transport and oil products storage. - 1996. - No.6. P. 4-9. 


\section{Ю. В. ЗЕЛЕНЬКО ${ }^{1}$, С. В. МЯМЛИН ${ }^{1 *}$ \\ ${ }^{1 *}$ Днепропетровский национальный университет железнодорожного транспорта имени академика В. Лазаряна, ул. Лаза- ряна, 2, Днепропетровск, Украина, 49010, тел. +38 (056) 37315 04, эл. почта: j.zelenko@mail.ru \\ ЭКОЛОГО-ЕКОНОМИЧЕСКИЕ МЕРЫ СТАБИЛИЗАЦИИ И УЛУЧШЕНИЯ СОСТОЯНИЯ ОКРУЖАЮЩЕЙ СРЕДЫ НА ЖЕЛЕЗНОДОРОЖНОМ ТРАНСПОРТЕ}

Проблемы обострения экологической ситуации во многих звеньях транспортных технологий обусловлены опережающими темпами развития транспорта и особенностями его взаимодействия с объектами окружающей среды. Цель. Необходимым этапом современного подхода к формированию эффективной системы экологического менеджмента на железнодорожном транспорте является создание специальной экоинформационной системы, позволяющей дать объективную оценку эколого-экономического ущерба как в процессе природопользования, так и в случаях аварийных инцидентов. Методика. Развитие систем управления окружающей средой при организации природопользования на основе современных информационных технологий позволит не только сократить частоту возникновения ситуаций, связанных с загрязнением элементов среды, но и оптимизировать организацию природопользования, поскольку высокая концентрация ресурсов может привести к появлению в смежных районах взаимоисключающих видов антропогенной деятельности. Научная новизна и практическое значение. Разработана система управления экологической безопасностью призвана определить наилучшие варианты развития природопользования с учетом экологических и экономических факторов. В процессе разработки научных основ управления экобезопасностью на транспорте был выполнен анализ трех основных концептуальных подходов к определению безопасности. Показано, что в последние годы благодаря интенсивному развитию фундаментальных наук возникли объективные предпосылки для создания методов измерения степени опасности на основе введения соответствующего показателя. Предложенный научно-методический аппарат предоставляет возможности оперативного управления эколого-экономическими рисками на железной дороге путем постоянного мониторинга с помощью ГИСтехнологий и системного анализа.

Ключевые слова: экологическая безопасность, железнодорожный транспорт, экоинформационная система, экологический ущерб 


\author{
Ю. В. ЗЕЛЕНЬКО ${ }^{1}$, С. В. МЯМЛІН ${ }^{1^{*}}$ \\ 1* Дніпропетровський національний університет залізничного транспорту імені академіка В.Лазаряна, ул. Лазаряна, 2, \\ Днепропетровск, Украина, 49010тел. +38 (056) 37315 04, эл. почта: j.zelenko@mail.ru
}

\title{
ЕКОЛОГО-ЕКОНОМІЧНІ ЗАХОДИ СТАБІЛІЗАЦІЇ ТА ПОЛІПШЕННЯ СТАНУ ДОВКІЛЛЯ НА ЗАЛІЗНИЧНОМУ TРАНСПОРТI
}

Проблеми загострення екологічної ситуації в галузі та посилення негативних тенденцій в багатьох ланках транспортних технологій зумовлені випереджаючими темпами розвитку транспорту та особливостями його взаємодії з об'єктами навколишнього природного середовища. Мета. Необхідним етапом сучасного підходу до формування ефективної системи екологічного менеджменту на залізничному транспорті є створення спеціальної екоінформаційної системи, що дозволить надати об'єктивну оцінку еколого-економічних збитків як в процесі природокористування, так і у випадках аварійних інцидентів з негативними екологічними наслідками. Методика. Розвиток систем управління навколишнім середовищем при організації природокористування на основі сучасних інформаційних технологій дозволить не тільки скоротити частоту виникнення ситуацій, пов'язаних із забрудненням елементів середовища, але і оптимізувати організацію природокористування, оскільки висока концентрація ресурсів може призвести до появи в суміжних районах взаємовиключних видів антропогенної діяльності. Наукова новизна та практичне значення. Розроблена система управління екологічним станом навколишнього середовища покликана визначити якнайкращі варіанти розвитку природокористування з урахуванням екологічних і економічних чинників. В процесі розробки наукових основ управління екологічною безпекою на транспорті було виконано аналіз трьох основних концептуальних підходів до визначення безпеки. Показано, що останніми роками, завдяки інтенсивному розвитку фундаментальних наук виникли об'єктивні передумови для створення методів вимірювання ступеня небезпеки на основі введення відповідного показника. Запропонований науково-методичний апарат надає можливості оперативного управління еколого-економічними ризиками на залізниці шляхом постійного моніторингу за допомогою ГІС-технологій та системного аналізу.

Ключові слова: екологічна безпека, залізничний транспорт, екоінформаційна система, екологічні збитки. 